\title{
Evaluating CERES-Maize Model Using Planting Dates and Nitrogen Fertilizer in Zambia
}

\author{
Charles Bwalya Chisanga ${ }^{1}$, Elijah Phiri $^{2}$, Chizumba Shepande ${ }^{2} \&$ Henry Sichingabula $^{3}$ \\ ${ }^{1}$ Ministry of Agriculture, Ndola, Zambia \\ ${ }^{2}$ University of Zambia, School of Agricultural Sciences, Department of Soil Science, Lusaka, Zambia \\ ${ }^{3}$ University of Zambia, School of Natural Science, Department of Geography and Environmental Studies, \\ Lusaka, Zambia
}

Correspondence: Charles Bwalya Chisanga, Ministry of Agriculture and Livestock, Box 70232, Ndola, Zambia. Tel: 260-955-885-667. E-mail: cbchisanga@gmail.com

$\begin{aligned} & \text { Received: November 4, } 2014 \\ & \text { Accepted: December 16, } 2014 \quad \text { Online Published: February 15, } 2015 \\ & \text { doi:10.5539/jas.v7n3p79 }\end{aligned} \quad$ URL: http://dx.doi.org/10.5539/jas.v7n3p79

\begin{abstract}
A field experiment was conducted during the 2013/2014 season to evaluate the performance of CERES-maize model in simulating the effect of date of planting, nitrogen fertilizer and root-zone soil water profile on growth and yield of maize (Zea mays L.) at the Field Research Station of the School of Agricultural Sciences, University of Zambia, Zambia $\left(15^{\circ} 23.6859^{\prime} \mathrm{S}, 28^{\circ} 20.226^{\prime} \mathrm{E}\right.$; 1,261 m.a.s.l). The experimental design was a split plot with three replicates, three planting dates (November 24, December 8, and December 22) assigned to main plots and two nitrogen fertilizer rates (112 and $168 \mathrm{~kg} \mathrm{~N}$ ha $^{-1}$ ) assigned to sub-plot. Phenological stages and aboveground biomass were used for model evaluation and these were observed at vegetative and reproductive stages. Soil water profiles were monitored using the Diviner 2000 Probe. Planting date significantly affected grain and biomass yield at $\mathrm{P}<0.05$. The coefficients of variation for grain and biomass yield were below $12 \%$ and considered efficient. The Generalized Likelihood Uncertainty Estimation (GLUE) programme was used to estimate the genetic coefficients for the CERES-maize model. The model's prediction of plant emergence $( \pm 1$ days), time to anthesis ( $\geq-3 \leq \pm 1$ days) and maturity ( $\geq-4 \leq 6$ days) was good. Simulation of biomass $(\mathrm{RMSE}=1135 \mathrm{~kg} / \mathrm{ha}, \mathrm{d}=0.96, \mathrm{EF}=0.86)$ was reasonably accurate while leaf area index $(\mathrm{d}=0.54, \mathrm{EF}=-0.65)$ was simulated with less accuracy due to poor d-stat and forecasting efficiency. The model's simulation of grain yield was fair (NRMSE $=21.4 \%$ ) while soil root water availability demonstrated that substantial potential yield may have been lost due to water stress. The results showed that the model can be used to accurately determine optimum planting date, biomass yield and nitrogen fertilizer rates with reasonable accuracy.
\end{abstract}

Keywords: biomass, calibration, CERES-maize, fertilizer application rate, GLUE, tops weight

\section{Introduction}

Maize (Zea mays L.) is the third most important cereal crop in the world after wheat and rice. It is grown across a wide range of climates but mainly in the warmer temperate regions and humid subtropics. Worldwide, maize is the most popular crop due to its high yielding per unit area and low cost of production and it is the major cereal staple crop in Zambia. In western countries maize production is highly mechanized whilst in many developing countries such as Zambia, smallholder and medium-scale farmers still use traditional and low-input technologies and yield under such conditions are generally low. Africa being a minor producer of maize by world standards, accounts only for $7 \%$ of global production. Average annual production was estimated at 49 million tons during the period 2005-2007; increasing from 32 million tons during the period 1985-1987. Additionally, most of the maize produced and consumed in Africa comes from smallholder rural farms. Rain-fed maize growing often suffers from water stress caused by erratic rainfall distribution and this is one of the major causes of maize yield reduction around the world. Water deficit, sub-optimum temperatures and low solar radiation levels are the most common adverse environmental condition that can seriously affect crop growth and reduce aboveground biomass and grain yield during the growing season.

Zambia Development Agency reported that maize is Zambia's staple crop and is grown in almost all parts of the country, mostly by small scale farmers ( 80 percent). Commercial farmers only account for about 20 percent of 
the country's annual total maize production. Maize cultivation in the country is mostly rain-fed. It provides 60 percent of all calories consumed in Zambia and it is the main priority crops for investment in the country.

Fertilizer application rates in the Sub-Saharan Africa (SSA) are very low (5-10 kg/ha), far below the target of 50 $\mathrm{kg} / \mathrm{ha}$ set by the Abuja Declaration and up to ten times smaller compared with more economically developed regions than SSA. Most maize planting recommendations are based on specific set of agronomic field experiments that are rarely repeatable overtime and space due to seasonal variation. The generation of new data through traditional agronomic research methods and its publication are not sufficient to meet increasing needs for new agro-technologies. Traditional fertilizer trials are conducted at particular points in time and space and this makes findings site and season specific, time consuming and expensive. Additionally, determining the optimum sowing dates for maize through field experimentation requires repeated trials for many years to capture rainfall variability. The experimental data for one area may not be relevant for another because of differences in rainfall distribution and soil type.

To achieve sustainable good yields integrated soil fertility management (ISFM) has been adopted and is defined as a set of soil fertility management practices that include the use of fertilizer, organic inputs, and improved germplasm, combined with knowledge on how to adapt these practices to local conditions, thus maximizing agronomic use efficiency of the applied nutrients and crop productivity. Decision support tools (DSTs) can be used in diagnosis and analysis of options for application of ISFM packages. DSTs such as crop simulation models are not widely used in sub-Saharan Africa due to lack of knowledge.

The Decision Support System for Agrotechnology Transfer (DSSAT) v4.5 is Windows-based computer programme that includes tools and utility programmes for managing soil, weather, genetic, crop, economic and pest data. It is supported by database management programmes for soil, genetics, weather, and crop management and experiment data files. It allows users to input, organize, store, retrieve and analyze crop, soil and weather data. The DSSAT comprises crop simulation models for over 28 crops with new tools that facilitate the creation and management of experiment, soil, and weather data files. The DSSAT was designed to simulate growth, development and yield of a crop growing on a uniform area of land under prescribed or simulated management as well as the changes in soil, water, carbon, and nitrogen that take place under the cropping system over time as a function of the soil-plant-atmosphere dynamics. Use of the DSSAT requires less use of agricultural inputs, scarce human, less experimentation, reduces overall costs, and yields better result in any given time frame and allows users to evaluate agro-technology packages. Crop models such as CERES-maize in DSSAT v4.5 can be used as decision support tools for optimizing nitrogen fertilizer management for a targeted crop yield while minimizing nutrient losses. Crop growth models have recently been used to study precision agriculture questions within the framework of a decision support system (DSS) that automates simulations using different crop management strategies.

The CERES-maize model is a predictive, deterministic model designed to simulate maize growth, soil water, and temperature and soil nitrogen dynamics at a field scale for one growing season (Jones \& Kiniry, 1986). A deterministic model is one that makes definite predictions for quantities without any associated probability distribution, variance, or random element. The CERES-Maize model has been extensively used worldwide to simulate maize growth and grain yield and as a tool for planning and decision making by farmers in several countries. While crop growth models such as CERES-Maize provide the ability to evaluate numerous management scenarios without the costs associated with multiyear field experiments, recent studies undertaken by have shown that CERES-Maize performs well under full irrigation. The CERES-Maize model simulates grain yield under water limiting conditions by calculating potential evaporation; potential soil water evaporation and potential plant water transpiration which are derived from potential evaporation and leaf area index. Consequently, based on the soil water supply and crop water demand, a water stress factor is estimated to decrease daily crop growth and grain yield.

Use of the CERES-maize model is a cost-effective methodology to examine the results of alternative crop management practices on agricultural production, estimate use efficiency of resources, and assess the sustainability of cropping systems. It is the most widely used maize model and is a recognized reference for comparing new developments in maize growth, development and yield simulation (Lizaso, et al., 2011). The model is able to accurately predict yield variability, nitrogen uptake and maize growth response to nitrogen. It can also be used to explore the potential of new cultivars for new areas before establishing costly field experiments and can also be used to determine the optimum planting dates (Soler et al., 2005). The CERES-Maize model has been tested and evaluated extensively by many researchers across location with good agreements between observed and simulated values for a wide range of experimental practices against field data and environmental conditions around the world. On the other hand, very few studies have been undertaken in 
Zambia to evaluate the CERES-Maize model. Therefore, the main objective of this study was to evaluate the performance of CERES-maize model in simulating the effect of planting date, nitrogen fertilizer and root-zone soil water profile on growth and yield of maize (Zea mays L.) on Ustic Isohyperthermic Paleausalf in Zambia.

\section{Materials and Methods}

\subsection{Field Experiment}

The field experiment was conducted at the School of Agricultural Sciences Field Station, University of Zambia, Lusaka (latitude $15^{\circ} 24^{\prime} \mathrm{S}$, longitude $28^{\circ} 20^{\prime} \mathrm{E}$ and elevation 1,261 meters above sea level). The experiment was a split plot design with three replicates. The main plots were the planting dates $\left(24^{\text {th }}\right.$ November $\left[\right.$ PD1], $8^{\text {th }}$ December [PD2] and $22^{\text {nd }}$ December [PD3] 2013) and subplots were nitrogen application rates (112 [N1] and 168 [N2] kg N/ha). Subplots were arranged in five rows of 5 meter length. ZMS 606 maize cultivar, a medium maturing three-way white maize hybrid - was used in the study whose maturity days range from 125-130 days. The hybrid has exceptional resistance to drought and all common maize diseases including GLS, MSV, leaf bright and corn rot. ZMS 606 maize cultivar was planted at 44,444 plants/ha, row spacing $(0.75 \mathrm{~m} \times 0.30 \mathrm{~m})$ and planted at a depth of $7 \mathrm{~cm}$. The recommended agronomic practices such as weeding were followed systematically.

\subsection{Plant Aboveground Biomass Measurements}

Biomass sampling procedure was done according to Ranson (2013), Hoogenboom et al. (1999) and IBSNAT (1988). One (1) meter row length of plants was marked with sticks at three observation units in each of the main plots. Observations at specific vegetative $(\mathrm{V})$ and reproductive $(\mathrm{R})$ stages were made on the 1-meter row length. The number of plants that had emerged were counted and recorded in each 1-meter row plant section on each day of observation. Twelve (12) representative plants inside the net plot were selected for monitoring the vegetative and reproductive stages. For the vegetative stage, phenological development was recorded by counting the number of true leaves with full collar. Aboveground biomass, plant growth analysis and grain yield were determined at $50 \%$ visible collar of 6 th leaf (V6), 50\% silk visible outside husks (R1), $50 \%$ "dough" stage (R4), 50\% physiological maturity (R6) and at harvest (R7). Fifty (50) plants were selected for the final harvest from the net plot to determine the ear number $\left(\right.$ ears $\mathrm{m}^{-2}$ ) and plant population (plants $\mathrm{m}^{-2}$ ). Other parameters included seed number (seeds $\left.\mathrm{m}^{-2}\right), 100$ seed weight $\left(\mathrm{g} \mathrm{m}^{-2}\right)$ ears number $\left(\right.$ ears $\left.\mathrm{m}^{-2}\right)$, cobs $\left(\mathrm{g} \mathrm{m}^{-2}\right)$, husks $\left(\mathrm{g} \mathrm{m}^{-2}\right)$, stover $\left(\mathrm{g} \mathrm{m}^{-2}\right)$, leaf blade $\left(\mathrm{g} \mathrm{m}^{-2}\right)$, leaf sheath $\left(\mathrm{g} \mathrm{m}^{-2}\right)$ and stem $\left(\mathrm{g} \mathrm{m}^{-2}\right)$. Preparation of plant samples was done according to the appropriate flow chart for maize.

\subsection{Canopy Cover Measurements}

The canopy cover $(\mathrm{CC})$ measurements were made at various times during the growing season using a digital camera. The leaf area index (LAI) for the three planting dates were computed from the $\mathrm{CC}$ using the following relationship for maize in Equation (1) below:

$$
C C=1.005[1-\exp (-0.6 L A I)]^{1.2}
$$

Where, $C C=$ Canopy cover; $L A I=$ Leaf area index.

\subsection{Weather and Soil Data Characterization}

\subsubsection{Climatic Characteristics}

The climate in the study area is subtropical with warm to wet hot summers and cool dry winters (Kottek, Grieser, Rudolf, \& Rubel, 2006) according to Koppen-Geiger climate classification. The study site was located in Agro-ecological Region II of Zambia which receives 800 to $1,000 \mathrm{~mm}$ of rainfall.

\subsubsection{Weather Conditions}

Daily maximum and minimum air temperature, rainfall and solar radiation data was obtained from an automated weather station of the School of Agricultural Sciences, University of Zambia situated adjacent to the field experimental site (Table 1). The cumulative total rainfall $(\mathrm{mm})(\mathrm{PD} 1=515.2, \mathrm{PD} 2=498.8$, PD3 $=476.6$ ), solar radiation $\left(\mathrm{MJ} \mathrm{m}^{-2} \mathrm{~d}^{-1}\right)(\mathrm{PD} 1=2308.7, \mathrm{PD} 2=2116.7, \mathrm{PD} 3=2269.6)$, and minimum $\left({ }^{\circ} \mathrm{C}\right)(\mathrm{PD} 1=16.9, \mathrm{PD} 2=$ $16.6, \mathrm{PD} 3=16.2)$ and maximum $\left({ }^{\circ} \mathrm{C}\right)(\mathrm{PD} 1=27.6, \mathrm{PD} 2=27.0, \mathrm{PD} 3=26.8)$ air temperature for each maize growing period were computed. 
Table 1. Monthly weather parameters during growing season of maize hybrid

\begin{tabular}{|c|c|c|c|c|c|}
\hline \multirow{2}{*}{ Month } & \multirow{2}{*}{$\begin{array}{l}\text { Precipitation } \\
(\mathrm{mm})\end{array}$} & \multirow{2}{*}{$\begin{array}{l}\text { Solar radiation } \\
\left(\mathbf{M J ~ m}^{-2} \mathbf{d}^{-1}\right)\end{array}$} & \multicolumn{2}{|c|}{ Temperature } & \multirow{2}{*}{$\begin{array}{l}\text { Relative humidity } \\
\text { (\%) }\end{array}$} \\
\hline & & & $\operatorname{Max}\left({ }^{\circ} \mathrm{C}\right)$ & Min $\left({ }^{\circ} \mathrm{C}\right)$ & \\
\hline Jun-13 & 0.0 & 16.8 & 13.3 & 9.4 & 0.0 \\
\hline Jul-13 & 0.0 & 18.0 & 23.1 & 9.4 & 0.0 \\
\hline Aug-13 & 0.0 & 18.8 & 26.2 & 12.3 & 0.0 \\
\hline Sep-13 & 0.0 & 20.0 & 31.0 & 16.5 & 0.0 \\
\hline Oct-13 & 56.8 & 19.7 & 30.0 & 17.5 & 5.0 \\
\hline Nov-13 & 93.0 & 19.8 & 30.4 & 18.9 & 9.0 \\
\hline Dec-13 & 141.8 & 18.5 & 28.6 & 18.0 & 17.0 \\
\hline Jan-14 & 155.4 & 16.6 & 27.4 & 17.5 & 26.0 \\
\hline Feb-14 & 99.8 & 14.9 & 26.6 & 17.8 & 18.0 \\
\hline Mar-14 & 85.6 & 17.3 & 27.3 & 16.8 & 14.0 \\
\hline Apr-14 & 87.2 & 16.7 & 25.6 & 14.9 & 5.0 \\
\hline May-14 & 0.0 & 17.9 & 24.9 & 12.0 & 0.0 \\
\hline
\end{tabular}

\subsubsection{Soil Data Characterization}

Soil characterization was done on soil at depths, 0-20, 20-40, 40-60, 60-100 cm. and classified as Ustic Isohyperthermic Paleausalf according to the USDA Soil Taxonomy. Soil physio-chemical and morphological properties were analyzed using standard methods and the results are presented in Table 2 and Table 3 . The $\mathrm{pH}$ of the soil was determined in water and calcium chloride. The total nitrogen was measured using the Kjeldahl and soil organic carbon $(\mathrm{OC})$ was determined using the Walkley and Black method. Bray I method was used to determine extractable phosphorus (P) while the exchangeable bases $\mathrm{Ca}^{2+}, \mathrm{Mg}^{2+}$ and $\mathrm{K}^{+}$were extracted with 1.0 $\mathrm{M}$ neutral $\mathrm{NH}_{4} \mathrm{OAc}$ extract (Black, 1965). Soil moisture content at lower limit (LL, 15 bars), drained upper limit (DUL, 1/3 bar), and at saturation (SAT) for various depths if not available could be estimated from percentages of sand, silt, and clay and bulk density. In this study the LL, DUL and SAT were estimated from textural analysis using the soil data tool-SBuild pedo-transfer functions in DSSAT.

Table 2. Soil physical analysis

\begin{tabular}{|c|c|c|c|c|c|c|}
\hline \multirow{2}{*}{$\begin{array}{l}\text { Parameters } \\
\text { measured }\end{array}$} & \multirow{2}{*}{ Units } & \multicolumn{4}{|c|}{ Layers (cm) } & \multirow{2}{*}{ Method of analysis } \\
\hline & & $0-20$ & $20-40$ & $40-60$ & $60-100$ & \\
\hline Soil textural class & & Loam & $\mathrm{SCL}$ & $\mathrm{CL}$ & $\mathrm{CL}$ & \multirow{4}{*}{$\begin{array}{l}\text { Hydrometer method } \\
\text { (Bouyoucos, 1962) }\end{array}$} \\
\hline Sand & $\%$ & 48.60 & 49.30 & 43.00 & 41.00 & \\
\hline Silt & $\%$ & 33.20 & 27.00 & 26.70 & 23.80 & \\
\hline Clay & $\%$ & 26.4 & 42.4 & 40.4 & 44.4 & \\
\hline Vol. Water Content & $\mathrm{cm}^{3} / \mathrm{cm}^{3}$ & 0.15 & 0.14 & 0.14 & 0.13 & \multirow{4}{*}{$\begin{array}{l}\text { (USDA, 1984) } \\
\text { (USDA, } \\
\text { Hoogenboom, Wilkens, \& } \\
\text { Tsuji, DSSAT v3, volume } \\
\text { 4, 1999) }\end{array}$} \\
\hline Vol. water PD1 & $\mathrm{cm}^{3} / \mathrm{cm}^{3}$ & 0.142 & 0.138 & 0.135 & 0.109 & \\
\hline Vol. water PD2 & $\mathrm{cm}^{3} / \mathrm{cm}^{3}$ & 0.155 & 0.139 & 0.146 & 0.141 & \\
\hline Vol. water PD3 & $\mathrm{cm}^{3} / \mathrm{cm}^{3}$ & 0.161 & 0.133 & 0.144 & 0.128 & \\
\hline DUL & $\mathrm{cm}^{3} / \mathrm{cm}^{3}$ & 0.303 & 0.393 & 0.365 & 0.477 & \multirow{2}{*}{$\begin{array}{l}\text { Soil data tool-SBuild } \\
\text { pedo-transfer functions in } \\
\text { DSSAT }\end{array}$} \\
\hline LL & $\mathrm{cm}^{3} / \mathrm{cm}^{3}$ & 0.176 & 0.254 & 0.237 & 0.302 & \\
\hline SAT & $\mathrm{cm}^{3} / \mathrm{cm}^{3}$ & 0.439 & 0.472 & 0.453 & 0.518 & $\begin{array}{l}\text { Gijsman, Jones, } \quad \& \\
\text { Hoogenboom, 2003) }\end{array}$ \\
\hline Bulk Density & $\mathrm{g} / \mathrm{cm}^{3}$ & 1.65 & 1.66 & 1.67 & 1.66 & $\begin{array}{l}\text { Core sampler technique } \\
\text { (USDA, 1984) }\end{array}$ \\
\hline
\end{tabular}


Table 3. Soil chemical analysis

\begin{tabular}{|c|c|c|c|c|c|c|}
\hline \multirow{2}{*}{$\begin{array}{l}\text { Parameters } \\
\text { measured }\end{array}$} & \multirow{2}{*}{ Units } & \multicolumn{4}{|c|}{ Layers (cm) } & \multirow{2}{*}{ Method of analysis } \\
\hline & & $0-20$ & $20-40$ & $40-60$ & $60-100$ & \\
\hline $\mathrm{pH}\left(\mathrm{CaCl}_{3}\right)$ & & 6.20 & 6.50 & 6.20 & 6.40 & \multirow{4}{*}{$\begin{array}{l}\text { Walkley-Black Method } \\
\text { Modified Kjeldahl's method (Page, Miller, \& } \\
\text { Keeney, 1982) }\end{array}$} \\
\hline pH (water) & & 6.5 & 6.7 & 6.9 & 6.9 & \\
\hline Organic carbon & $\%$ & 0.66 & 0.60 & 0.34 & 0.18 & \\
\hline Total nitrogen & $\%$ & 0.06 & 0.04 & 0.02 & 0.01 & \\
\hline P extractable & $\mathrm{mg} / \mathrm{kg}$ & 33.00 & 19.00 & 8.00 & 3.00 & \multirow{2}{*}{$\begin{array}{l}\text { Bray } 1 \text { method (USDA, 1984) } \\
\text { Modified Kjeldahl's method (Page, Miller, \& } \\
\text { Keeney, 1982) }\end{array}$} \\
\hline $\mathrm{NH}_{4}$ & $\mathrm{meq} / 100 \mathrm{~g}$ & 0.06 & 0.04 & 0.03 & 0.05 & \\
\hline $\mathrm{NO}_{3}$ & $\mathrm{meq} / 100 \mathrm{~g}$ & 0.03 & 0.04 & 0.03 & 0.05 & $\begin{array}{l}\text { Modified Kjeldahl's method (Page, Miller, \& } \\
\text { Keeney, 1982) }\end{array}$ \\
\hline K exchangeable & $\mathrm{cmol} / \mathrm{kg}$ & 0.45 & 0.08 & 0.24 & 0.06 & \multirow{4}{*}{ Ammonium acetate (Black, 1965) } \\
\hline $\mathrm{Ca}^{2}+$ exchangeable & $\mathrm{cmol} / \mathrm{kg}$ & 3.74 & 1.36 & 2.77 & 1.09 & \\
\hline Magnesium & $\mathrm{mg} / \mathrm{kg}$ & 79.00 & 31.00 & 81.00 & 55.00 & \\
\hline CEC & $\mathrm{cmol} / \mathrm{kg}$ & 12.00 & 10.00 & 15.00 & 8.00 & \\
\hline
\end{tabular}

\subsubsection{Soil Water Content Measurements}

The access tubes were installed at the center of each subplot and soil water content readings taken two to three times per week at $10 \mathrm{~cm}$ interval to a depth of $160 \mathrm{~cm}$ using Diviner 2000 series II probe. A series of readings taken by the Diviner 2000 series II help to show trends in crop water use in the soil profile. To summarize the measured soil water content with the Diviner probe was simulated with CERES-maize and analyzed for the ZMS 606 cultivar.

\subsection{Analysis of Variance}

Analysis of variance (ANOVA) is a collection of statistical models used to analyze the differences between group means and their associated procedures. Comparison of treatments effects for observed data were analyzed using ANOVA and mean separation by Least Square Difference (LSD) using GenStat version 16 for Split-plot design.

\subsection{Modeling Procedure}

\subsubsection{CERES-Maize Model Description}

The DSSAT CERES-maize model is a maize growth simulation model that describes daily phenological development in response to environmental factors. The CERES-maize model is cultivar-specific and site-specific and operates on a daily time step. It dynamically simulates the development of roots and shoots, the growth and senescence of leaves and stems, biomass accumulation, and the growth of maize grain yield as a function of soil and weather conditions, crop management practices, and cultivar characteristics. The CERES-maize model uses common soil $\mathrm{C} / \mathrm{N}$ and water models, which integrate mathematical equations to describe the basic flow and conversion processes of soil carbon, water and nutrient balances on a daily or hourly basis. At the same time, it also predicts the temporal changes in crop growth, nutrient uptake, water use, final yield as well as other plant traits and outputs. Besides simulating maize growth, development and yield, the CERES-maize model also assesses the commencement of the phenological phases that depend on genetic coefficients and weather conditions, leaf, stem and root growth. By including nitrogen and water balance in the model it is possible to optimally use fertilizers to realize nutrition and water storage in the plant.

The Generalized Likelihood Uncertainty Estimation (GLUE) programme in DSSAT v4.5 was used to estimate CSPs for the CERES-maize model. The GLUE CSP estimation method was integrated into DSSAT v4.5 using the $\mathrm{R}$ language (Note 1), a free software environment for statistical computing and graphics. The data set required to calibrate the CSPs using GLUE included dates of emergence, anthesis, and physiological maturity, grain yield, above ground biomass, grain density $\left(\right.$ grains $\mathrm{cob}^{-1}$ ) and individual grain weight. The CERES-maize model uses six CSPs that affect development rates, yield and yield components. According to these six genetic coefficients or cultivar specific parameters (CSPs) for maize are: the values of the thermal time from seed 
emergence to the end of the juvenile stage (P1), the photoperiod sensitivity coefficient $(0-1.0)(\mathrm{P} 2)$, thermal time from silking to physiological maturity measured in degree days above a base temperature of $8^{\circ} \mathrm{C}(\mathrm{P} 5)$, potential kernel number per plant (G2), potential grain filling rate in $\mathrm{mg} \mathrm{day}^{-1}(\mathrm{G} 3)$ and interval in degree days between successive leaf tip appearance (phyllochron interval) (PHINT). (Jones, He, Boote, Wilkens, Porter, \& Hu, Estimating DSSAT Cropping System Cultivar-Specific Parameters Using Bayesian Techniques, 2011) reported that in using the GLUE, the parameter space is first discretized by generating a large number (6000) of parameter values from the prior distribution. Likelihood values are then calculated for each set of coefficients using differences between model predictions and measurements. Weights and probabilities are calculated with the Bayesian equation, and the posterior coefficients are estimated.

\subsubsection{CERES-Maize Model Input Files}

The basic input data required by the CERES-Maize model includes (Figure 1): (i) daily weather data (maximum and minimum temperature, precipitation, solar radiation), (ii) soil data, including initial soil water content, nitrate, and ammonium and soil layer thickness, (iii) crop management data and (iv) the cultivar-specific parameters (CSPs) or genetic coefficients that describe physiological processes and developmental differences among crop hybrids or varieties. Key levels of water availability for each soil layer required includes: SAT, DUL and LL. Leaf area index (LAI) measurements provide indices of plant growth with time and are normally used as inputs for crop simulation models.

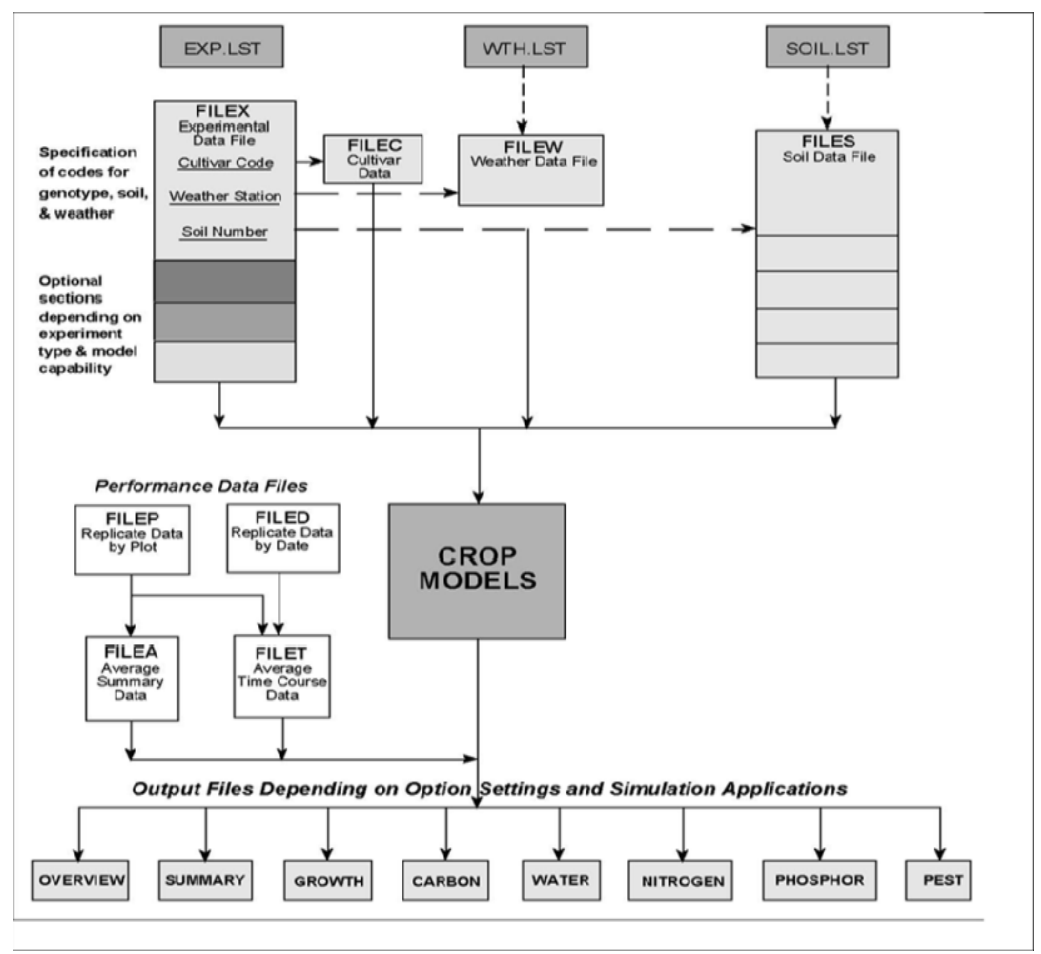

Figure 1. Overview of input and output files used by DSSAT crop models (DSSAT4.5 Vol. 1, 2010)

\subsubsection{Evaluation of the CERES-Maize Model}

According to there are three levels or groups of crop simulation models. Level 1 defines the data required for model applications, Level 2 defines the data required for general model evaluation, and Level 3 defines the data required for detailed model calibration and evaluation. The CERES-maize model was calibrated with data obtained from the 2013/2014 rain-fed experiment and evaluated using phenological dates, aboveground biomass yield and yield components. The statistical indicators of percentage difference, the index of agreement (d) (Willmott, 1982), root mean square error (RMSE) and the normalized RMSE (NRMSE) (Soler et al., 2007) were computed to determine the degree of predictability according to Equations (2), (3), (4) and (5). In addition, the degree that each simulated value deviates from the corresponding observed value can be evaluated by calculating the percentage of Predicted Deviation (PD) using Equation (2). $S_{i}$ and $O_{i}$ refer to the simulated and observed values for the studied variables. A negative deviation indicated an under-prediction, while a positive deviation 
indicated an over-prediction. The RMSE were used to determine statistical differences between simulated and measured yields. The closer the $d$-stat values to unit, the better the simulation.

$$
\begin{gathered}
P D=\frac{O_{i}-S_{i}}{O_{i}} \\
d=1-\left[\frac{\sum\left(P_{i}-O_{i}\right)^{2}}{\sum\left(\left|P_{i}^{\prime}\right|+\mid O_{i}^{\prime}\right)^{2}}\right] \\
R M S E=\sqrt{\frac{1}{n} \sum_{1}^{n}\left(X_{S}-X_{O}\right)^{2}}
\end{gathered}
$$

Where $n$ represents the number of comparisons, $\mathrm{X}_{\mathrm{S}}$ is the simulated yield for a treatment, and $\mathrm{X}_{\mathrm{O}}$ is observed yield. The NRMSE was calculated according to the following formula:

$$
\text { NRMSE }=\frac{R M S E}{\bar{X}} \times 100 \%
$$

Where RMSE was calculated from Equation (2). $\bar{X}$ was the average observed yield. According to (Kiniry, et al., 1997) RMSE is widely used as a standard for model evaluation. The NRMSE gives the level of error associated with each evaluation between the observed and simulated outcome. Soler et al. (2007) noted that the prediction is considered excellent (NRMSE: $<10 \%$ ), good (NRMSE: $>10 \%<20 \%$ ), fair (NRMSE: $>20 \%<30 \%$ ) and poor (NRMSE: $>30 \%$ ). The NRMSE and PD value of 0 indicated that there was better simulation of the parameters by the model. Other statistics used included mean error (ME or E) and forecasting efficiency (EF). The E was used to identify whether the model prediction trends were over or under-estimated. The observed and simulated values of maize emergence, anthesis, and maturity stages, aboveground biomass and grain yield were compared in this study.

\subsubsection{Model Outputs}

The CERES-maize model simulation consisted of an Experiment file (FileX), which defines crop management for a particular experiment (set of model runs or treatments) and references soil data (FileS), cultivar data (FileC) , and weather data (FileW), in-season growth data (FileT) and summary averages (FileA) data files. These files are separated in this way because soil definitions and weather data can be used in several simulations and different crops, whereas the experimental file is unique to a particular experiment (Jones \& Singles, 2008). The model creates a number of output files for each simulation run as shown in Figure 1.

\subsection{Seasonal Analysis}

The calibrated CERES-maize model was used to simulate maize yields through seasonal analysis program utilizing the same weather data, soil data, cultivar and experimental file in performing multiple runs of the model for one season. In undertaking seasonal analysis, three basic steps were followed: (i) creation of an appropriate CERES-maize model input file; (ii) running CERES-maize model using seasonal analysis program; and (iii) biophysical analysis of the results of the simulation using the seasonal analysis program. The seasonal analysis option of DSSAT was utilized to simulate the optimum planting date and $\mathrm{N}$ application rate.

\section{Results}

\subsection{Planting Data Analysis}

The harvest at maturity of aboveground biomass and grain were affected by planting date and highly significant at $\mathrm{P}<0.05$ as presented in Table 4, Table 5 and Table 6 . The maize husks, stover and leaf sheath were significantly affected by planting date at $\mathrm{P}<0.05$. Results showed that grain yield at each treatment level reduced with delay in planting date. The total aboveground biomass varied from 10.38 to 13.61 ton ha ${ }^{-1}$ and grain yield production varied from 7.6 to 10.7 ton $\mathrm{ha}^{-1}$, separated by 14-day interval which significantly reduced biomass production. The R-Square and RMSE for the grain were 0.87 and $75.99 \mathrm{~g} \mathrm{~m}^{-1}$ respectively while biomass R-Square and RMSE were 0.87 and $94.98 \mathrm{~g} \mathrm{~m}^{-1}$ respectively. There was no interaction effect between planting date and nitrogen application rates. 
Table 4. ANOVA of grain yield

\begin{tabular}{llllll}
\hline Source & DF & Anova SS & Mean square & F value & $\operatorname{Pr}>$ F \\
\hline Planting date $(\mathrm{PD})$ & 2 & 242412.3 & 121206.2 & 20.99 & 0.0003 \\
N rate & 1 & 2626.7 & 2626.7 & 0.45 & 0.5153 \\
Block & 2 & 113305.8 & 56652.9 & 9.81 & 0.0044 \\
PD*N rate & 2 & 34649.0 & 17324.5 & 3.00 & 0.0954 \\
\hline
\end{tabular}

Table 5. ANOVA of aboveground biomass

\begin{tabular}{llllll}
\hline Source & DF & Anova SS & Mean square & F value & Pr $>$ F \\
\hline Planting date (PD) & 2 & 364337.8 & 182168.9 & 20.19 & 0.0003 \\
N rate & 1 & 15127.6 & 15127.6 & 1.68 & 0.2244 \\
Block & 2 & 170279.1 & 85139.5 & 9.44 & 0.0050 \\
PD*N rate & 2 & 69672.7 & 34836.4 & 3.86 & 0.0572 \\
\hline
\end{tabular}

Table 6. Harvest at maturity - yield and yield components as affected by planting date and $\mathrm{N}$ rate

\begin{tabular}{|c|c|c|c|c|c|c|c|c|c|}
\hline \multirow{2}{*}{ Treatment } & \multicolumn{9}{|c|}{ Harvest at maturity $(\mathrm{R} 7) \mathrm{g} / \mathrm{m}^{2}$} \\
\hline & Biomass & Grain & HI & Cob & Stem & Leaf blade & Husk & Stover & Leaf sheath \\
\hline PD1 & $1361^{\mathrm{b}}$ & $1012^{\mathrm{b}}$ & $0.75^{\mathrm{a}}$ & $134.0^{\mathrm{a}}$ & $93.7^{\mathrm{a}}$ & $33.0^{\mathrm{a}}$ & $60.8^{\mathrm{b}}$ & $349.5^{\mathrm{b}}$ & $28.02^{\mathrm{a}}$ \\
\hline PD2 & $1087^{\mathrm{a}}$ & $783^{\mathrm{a}}$ & $0.72^{\mathrm{a}}$ & $121.2^{\mathrm{a}}$ & $93.5^{\mathrm{a}}$ & $28.8^{\mathrm{a}}$ & $36.1^{\mathrm{a}}$ & $303.7^{\mathrm{ab}}$ & $24.08^{\mathrm{a}}$ \\
\hline PD3 & $1038^{\mathrm{a}}$ & $751^{\mathrm{a}}$ & $0.72^{\mathrm{a}}$ & $121.3^{\mathrm{a}}$ & $72.1^{\mathrm{a}}$ & $26.7^{\mathrm{a}}$ & $43.7^{\mathrm{a}}$ & $286.9^{\mathrm{a}}$ & $23.13^{\mathrm{a}}$ \\
\hline Significance & $* *$ & $* *$ & NS & NS & NS & NS & $*$ & $*$ & $*$ \\
\hline LSD 5\% & 122.2 & 97.8 & 0.034 & 14.26 & 43.80 & 6.29 & 13.64 & 50.22 & 24.85 \\
\hline N1 & 1133 & 836 & 0.7352 & 123.0 & 75.9 & 28.3 & 44.5 & 296.4 & 25.31 \\
\hline N2 & 1191 & 861 & 0.7217 & 128.0 & 97.0 & 30.7 & 49.2 & 330.3 & 330.3 \\
\hline Significance & NS & NS & NS & NS & NS & NS & NS & NS & NS \\
\hline LSD 5\% & 99.6 & 79.8 & 0.028 & 11.64 & 35.76 & 5.14 & 11.14 & 41.01 & 3.597 \\
\hline $\mathrm{cv} \%$ & 8.2 & 9.0 & 3.7 & 8.8 & 39.4 & 16.6 & 22.6 & 12.5 & 13.7 \\
\hline \multicolumn{10}{|c|}{ Interaction $(\mathrm{PD} * \mathrm{~N}$ rate $)$} \\
\hline Significance & NS & NS & NS & NS & NS & NS & NS & NS & NS \\
\hline LSD 5\% & 172.8 & 138.2 & 0.048 & 20.16 & 61.94 & 8.90 & 19.30 & 71.03 & 6.231 \\
\hline
\end{tabular}

Note. Means sharing same letter in the table do not differ statistically at $\mathrm{p} \leq 0.05$; $\mathrm{cv}$ : coefficient of variation; PD1 = First planting date; PD2 = Second planting date; PD3 = Third planting date; N1 = $112 \mathrm{~kg} \mathrm{~N} / \mathrm{ha} ; \mathrm{N} 2=168$ $\mathrm{kg} \mathrm{N} / \mathrm{ha}$; LSD $=$ Least Mean Differences; $*=$ Significant at $5 \%$ level; $* *=$ Highly significant at $5 \%$; NS $=$ Non significant.

\subsection{CERES-Maize Model Calibration}

Model calibration is the adjustment of cultivar specific parameters (CSPs) so that simulated values compare well with observed field data (Jones, Hoogenboom, Wilkens, Porter, \& Tsuji, 2010a). The "P" CSPs (P1, P2 and P5) were computed using observed anthesis and physiological maturity dates. The "P" CSPs are used to determine the timing of the phenological events such as dates of anthesis and maturity of maize. The G2 and G5 CSPs control the yield-related outputs such as grain dry matter yield, grain size and aboveground biomass weight. Detailed descriptions of the phenological development parameters used by the CERES-maize model are presented in Table 7. The computed CSPs values for ZMS606 cultivar were copied into the cultivar (CUL) file (MZCER045.CUL) to operate the simulation and model evaluation. 
Table 7. CERES-maize genetic coefficients for ZMS 606 cultivar

\begin{tabular}{lll}
\hline Cultivar Specific Parameters & Development Aspects & Values \\
\hline P1 & Thermal time (base $8{ }^{\circ} \mathrm{C}$ ) from seedling emergence to the end of & 213.8 \\
& the juvenile phase & 0.831 \\
P2 & Photoperiod sensitivity coefficient (0-1.0) & 822.5 \\
P5 & Thermal time (base $8{ }^{\circ} \mathrm{C}$ ) from silking to physiological maturity & 979.7 \\
\hline G2 & Growth Aspects & 9.791 \\
G3 & Maximum possible number of kernels per plant & \\
& Kernel filling rate during the linear grain filling stage and under & 60.00 \\
PHINT & optimum conditions (mg/kernel d) & \\
& Phyllochron interval; the interval in thermal time (degree days) & \\
\hline
\end{tabular}

\subsection{Growth and Development}

\subsubsection{Phenological Development Phases}

After calibrating the model, comparisons were made between observed and simulated outputs. Percent deviation of the simulated from the observed were computed and results on modeled prediction on emergence, anthesis, and physiological maturity dates and grain yield are presented in Table 8 . The close agreement between the observed and simulated values for emergence, anthesis (silking) and maturity dates for PD1, PD2 and PD3 indicated that good phenological CSPs were assigned to ZMS606 cultivar used in this study. The differences between observed and simulated emergence day (dap), anthesis day (dap) and physiological maturity day (dap) were $\pm 1, \geq-3 \leq \pm 1$ and $\geq-4 \leq 6$ days, respectively. Phenological phases deviation from the observed were from $-4.0 \%$ to $14.0 \%$ (Table 8 ). The number of leaves per stem was predicted with good accuracy while leaf area index (LAI) was simulated with less accuracy as indicated by the NRMSE (Table 10). Simulation of LAI with less accuracy can also be seen in the percent deviations which ranged from 45 to $60 \%$ and 52 to $68 \%$ for N1 and N2, respectively. Pooled data of LAI (Figure 3) indicated that the simulation efficiency was poor as can be seen from the index of agreement $(\mathrm{d}$-stat $=0.54)$ and forecasting efficiency $(E F=-0.65)$. 
Table 8. A comparison between observed and simulated and percentage difference for phenological development stages of maize under three planting dates and two nitrogen rates with the CERES-Maize model

\begin{tabular}{|c|c|c|c|c|c|c|}
\hline & \multicolumn{2}{|c|}{ PD1N1 } & \multirow{2}{*}{$\%$ Deviation } & \multicolumn{2}{|c|}{ PD1N2 } & \multirow{2}{*}{$\%$ Deviation } \\
\hline & Measured & Simulated & & Measured & Simulated & \\
\hline Emergence day (dap) & 7 & 6 & 14 & 7 & 6 & 14 \\
\hline Anthesis day (dap) & 70 & 69 & 1 & 70 & 69 & 1 \\
\hline Physiological maturity day (dap) & 133 & 127 & 5 & 133 & 127 & 5 \\
\hline LAI & 3.24 & 1.78 & 45 & 4.66 & 1.58 & 66 \\
\hline \multirow[t]{3}{*}{ Leaf number per stem at maturity } & 14 & 16 & -14 & 14 & 16 & -16 \\
\hline & \multicolumn{2}{|c|}{ PD2N1 } & \multirow{2}{*}{$\%$ Deviation } & \multicolumn{2}{|c|}{ PD2N2 } & \\
\hline & Measured & Simulated & & Measured & Simulated & \%Deviation \\
\hline Emergence day (dap) & 8 & 7 & 13 & 8 & 7 & 13 \\
\hline Anthesis day (dap) & 70 & 70 & 0 & 70 & 70 & 0 \\
\hline Physiological maturity day (dap) & 128 & 131 & -2 & 128 & 131 & -2 \\
\hline LAI & 3.48 & 1.39 & 60 & 4.19 & 2.03 & 52 \\
\hline \multirow[t]{3}{*}{ Leaf number per stem at maturity } & 15 & 16 & -4 & 15 & 16 & -4 \\
\hline & \multicolumn{2}{|c|}{ PD3N1 } & $0 /$ Deviation & \multicolumn{2}{|c|}{ PD3N2 } & $0 /$ Deviation \\
\hline & Measured & Simulated & $\%$ Deviation & Measured & Simulated & \%Deviation \\
\hline Emergence day (dap) & 6 & 6 & 0 & 6 & 6 & 0 \\
\hline Anthesis day (dap) & 67 & 70 & -4 & 67 & 70 & -4 \\
\hline Physiological maturity day (dap) & 132 & 134 & -2 & 132 & 134 & -2 \\
\hline LAI & 3.05 & 1.33 & 56 & 4.68 & 1.49 & 68 \\
\hline Leaf number per stem at maturity & 14 & 16 & -18 & 14 & 16 & -18 \\
\hline
\end{tabular}

\subsubsection{Grain Yield and Final Biomass}

The tops (aboveground biomass) weight at anthesis and maturity percent deviation from observed ranged from $-2 \%$ to $39 \%$ and $-8 \%$ to $45 \%$ for $\mathrm{N} 1$ and $\mathrm{N} 2$, respectively. The percent deviation of grain yield ranged from $8 \%$ to $29 \%$ and $3 \%$ to $23 \%$ for N1 and N2, respectively as shown in Table 9. Harvest index at all treatment levels were under-predicted and the percent deviation at all treatment levels ranged from $8 \%$ to $19 \%$. Comparison of grain yield using standard error bars (Figure 2) indicated that there was no significant difference between the observed and simulated grain yield at PD2N1, PD2N2 and PD3N2 as presented in Table 9. On the other hand, there were significant difference between observed and simulated grain yield for PD1N1, PD1N2 and PD3N1. The overall grain yield RMSE and NRMSE were 1.8 tons[dm]/ha and $21.4 \%$, respectively and according to Soler et al. (2007) the simulation of grain yield was fair.

The model's simulation of tops weight was good (PD1N1), poor (PD1N2), fair (PD2N1), poor (PD2N2 and PD1) at all treatment levels. The index of agreement (0.92-0.98) for the aboveground biomass was good at all treatment levels. Pooled data of tops weight indicated that the forecasting efficiency, RMSE and d-stat were 0.87, $1135.24 \mathrm{~kg} / \mathrm{ha}$ as presented in Figure 3. 
Table 9. A comparison between observed and simulated and percentage difference for grain and biomass yield of maize under three planting dates and two nitrogen rates with the CERES-Maize model

\begin{tabular}{|c|c|c|c|c|c|c|}
\hline & \multicolumn{2}{|c|}{ PD1N1 } & \multirow{2}{*}{ \%Deviation } & \multicolumn{2}{|c|}{ PD1N2 } & \multirow{2}{*}{ \% Deviation } \\
\hline & Measured & Simulated & & Measured & Simulated & \\
\hline Tops weight at anthesis $(\mathrm{kg}[\mathrm{dm}] / \mathrm{ha})$ & 4,597 & 3,097 & 33 & 5,794 & 3,185 & 45 \\
\hline Tops weight at maturity $(\mathrm{kg}[\mathrm{dm}] / \mathrm{ha})$ & 12,586 & 10,877 & 14 & 14,635 & 12,389 & 15 \\
\hline Grain yield $(\mathrm{kg}[\mathrm{dm}] / \mathrm{ha})$ & 9,511 & 6,783 & $29 *$ & 10,720 & 8,249 & $23^{*}$ \\
\hline \multirow[t]{3}{*}{ Harvest index at maturity } & 0.76 & 0.624 & 18 & 0.73 & 0.666 & 9 \\
\hline & \multicolumn{2}{|c|}{ PD2N1 } & & \multicolumn{2}{|c|}{ PD2N2 } & \\
\hline & Measured & Simulated & $\%$ Deviation & Measured & Simulated & $\%$ Deviation \\
\hline Tops weight at anthesis $(\mathrm{kg}[\mathrm{dm}] / \mathrm{ha})$ & 4,307 & 2,619 & 39 & 4,750 & 2,765 & 42 \\
\hline Tops weight at maturity $(\mathrm{kg}[\mathrm{dm}] / \mathrm{ha})$ & 10,527 & 10,790 & -2 & 11,213 & 11,788 & -5 \\
\hline Grain yield (kg $[\mathrm{dm}] / \mathrm{ha})$ & 7,618 & 6,991 & 8 & 8,049 & 7,825 & 3 \\
\hline \multirow[t]{3}{*}{ Harvest index at maturity } & 0.72 & 0.65 & 10 & 0.72 & 0.66 & 8 \\
\hline & \multicolumn{2}{|c|}{ PD3N1 } & & \multicolumn{2}{|c|}{ PD3N2 } & \\
\hline & Measured & Simulated & \%Deviation & Measured & Simulated & \%Deviation \\
\hline Tops weight at anthesis $(\mathrm{kg}[\mathrm{dm}] / \mathrm{ha})$ & 3,788 & 2,684 & 29 & 4,766 & 2,902 & 39 \\
\hline Tops weight at maturity $(\mathrm{kg}[\mathrm{dm}] / \mathrm{ha})$ & 10,873 & 9,636 & 11 & 9,879 & 10,635 & -8 \\
\hline Grain yield (kg $[\mathrm{dm}] / \mathrm{ha})$ & 7,965 & 5,667 & $29 *$ & 7,049 & 6,402 & 9 \\
\hline Harvest index at maturity & 0.73 & 0.59 & 19 & 0.71 & 0.6 & 15 \\
\hline
\end{tabular}

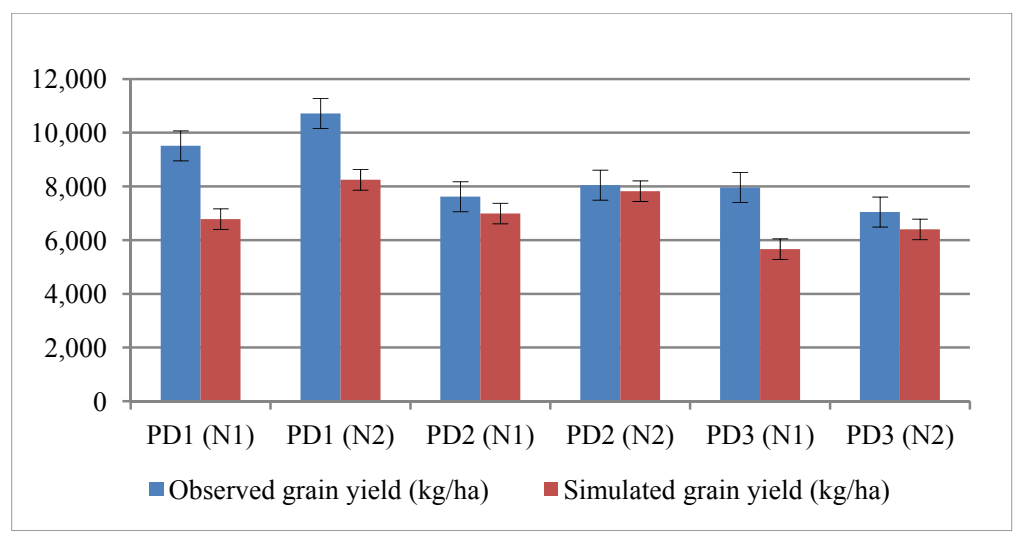

Figure 2. Observed versus simulated grain yield 
Table 10. Descriptive statistics showing the performance of CERES-Maize

\begin{tabular}{|c|c|c|c|c|c|c|c|c|}
\hline \multirow{2}{*}{$\begin{array}{l}\text { First planting date } \\
\text { Crop characteristics }\end{array}$} & \multicolumn{4}{|c|}{ N1 } & \multicolumn{4}{|c|}{ N2 } \\
\hline & RMSE & d-stat & $\mathrm{R} 2$ & NRMSE & RMSE & d-stat & $\mathrm{R} 2$ & RRMSE \\
\hline Tops weight (kg/ha) & 669.63 & 0.98 & 0.97 & 15.52 & 1595.77 & 0.95 & 0.97 & 30.09 \\
\hline LAI & 1.09 & 0.55 & 0.45 & 55.05 & 1.41 & 0.49 & 0.24 & 65.46 \\
\hline Leaf number & 1.90 & 0.94 & 1.00 & 15.80 & 1.90 & 0.94 & 1.00 & 15.80 \\
\hline Seconda planting date & \multicolumn{4}{|c|}{ N1 } & \multicolumn{4}{|c|}{ N2 } \\
\hline Crop characteristics & RMSE & d-stat & $\mathrm{R} 2$ & NRMSE & RMSE & d-stat & $\mathrm{R} 2$ & RRMSE \\
\hline Tops weight (kg/ha) & $1,563.15$ & 0.96 & 0.87 & 29.27 & $1,900.15$ & 0.94 & 0.83 & 33.38 \\
\hline LAI & 0.54 & 0.55 & 0.73 & 56.50 & 0.62 & 0.49 & 0.66 & 62.10 \\
\hline Leaf number & 1.49 & 0.54 & 0.58 & 65.64 & 1.27 & 0.57 & 0.41 & 63.18 \\
\hline Third planting date & \multicolumn{4}{|c|}{ N1 } & \multicolumn{4}{|c|}{$\mathrm{N} 2$} \\
\hline Crop characteristics & RMSE & d-stat & $\mathrm{R} 2$ & NRMSE & RMSE & d-stat & $\mathrm{R} 2$ & RRMSE \\
\hline Tops weight (kg/ha) & $1,738.47$ & 0.93 & 0.80 & 37.78 & $2,009.81$ & 0.92 & 0.77 & 36.99 \\
\hline LAI & 0.39 & 0.71 & 0.71 & 43.10 & 0.51 & 0.55 & 0.21 & 54.50 \\
\hline Leaf number & 1.15 & 0.59 & 0.31 & 69.70 & 1.89 & 0.55 & 0.34 & 78.22 \\
\hline
\end{tabular}
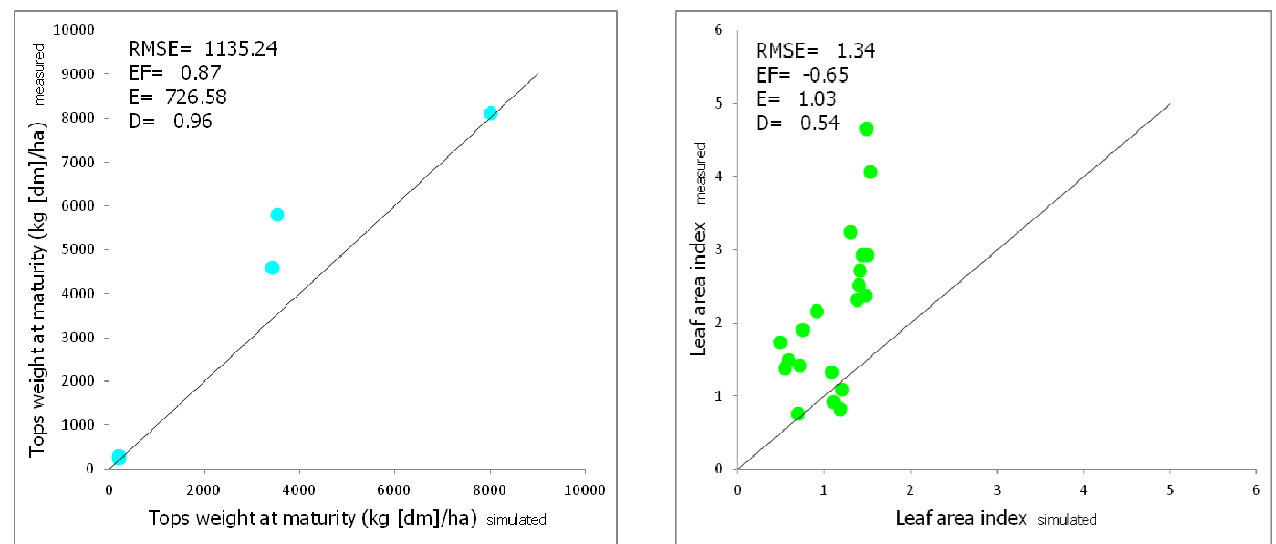

Figure 3. Observed versus Simulate (i) aboveground biomass (ii) leaf area index

\subsubsection{Soil Water Content Simulation and the Model's Response to Two N Application Rates}

Two $\mathrm{N}$ application rates (112 and $168 \mathrm{~N} \mathrm{~kg} / \mathrm{ha}$ ) were used at each of the planting dates. Observed and simulated aboveground biomass and grain yield were higher for $168 \mathrm{~kg} \mathrm{~N} / \mathrm{ha}$ application rate compared to $112 \mathrm{~kg} \mathrm{~N} / \mathrm{ha}$ at all treatment levels. Observed field data and simulated outcome of grain yield and tops weight showed a decrease in dry matter accumulation with delay in planting dates. According to the simulation the $\mathrm{N}$ uptake during the maize growing season was 127 (PD1N1), 166 (PD1N2), 129 (PD2N1), 170 (PD2N2), 130 (PD3N1) and 170 (PD3N2) $\mathrm{kg}$ [N uptake]/ha. The accumulation of dry matter was also affect with reduction in precipitation, air temperature and solar radiation. Water stress in maize increased with reducing rainfall and this contributed to grain yield reduction as the season progressed (Ollenburger, 2012). Simulation of soil root water availability demonstrated that substantial potential yield may have been lost due to water stress under rain-fed conditions especially for the third date of planting (Figure 4). 


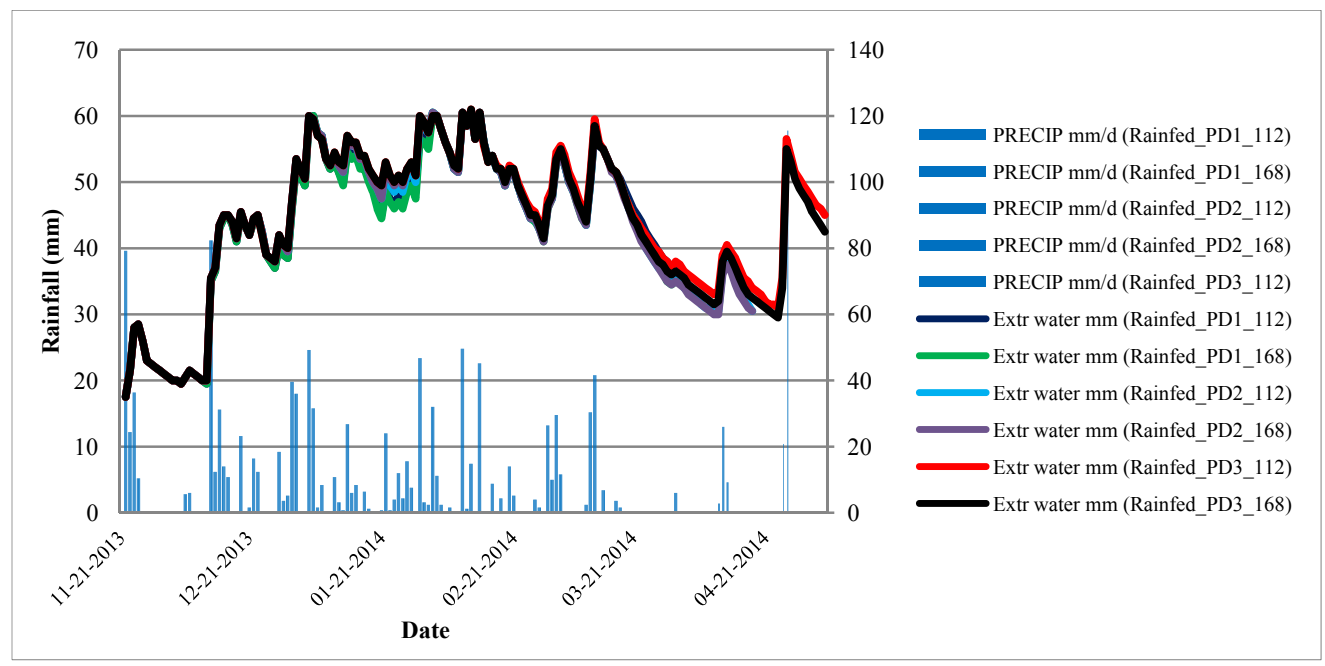

Figure 4. Extractable soil water content versus rainfall

The CERES-maize model overestimated available soil water in each soil profile during the crop's growing season for all treatments as shown in Figure 5. The soil water content for the three PDs were simulated for soil layer $1(\mathrm{~d}$-stat $=0.62)$, layer $2(\mathrm{~d}$-stat $=0.55)$, layer $3(\mathrm{~d}$-stat $=0.50)$ and layer $4(\mathrm{~d}$-stat $=0.23)$. The CERES-maize model over-predicted the availability of soil water for the fourth soil layer.
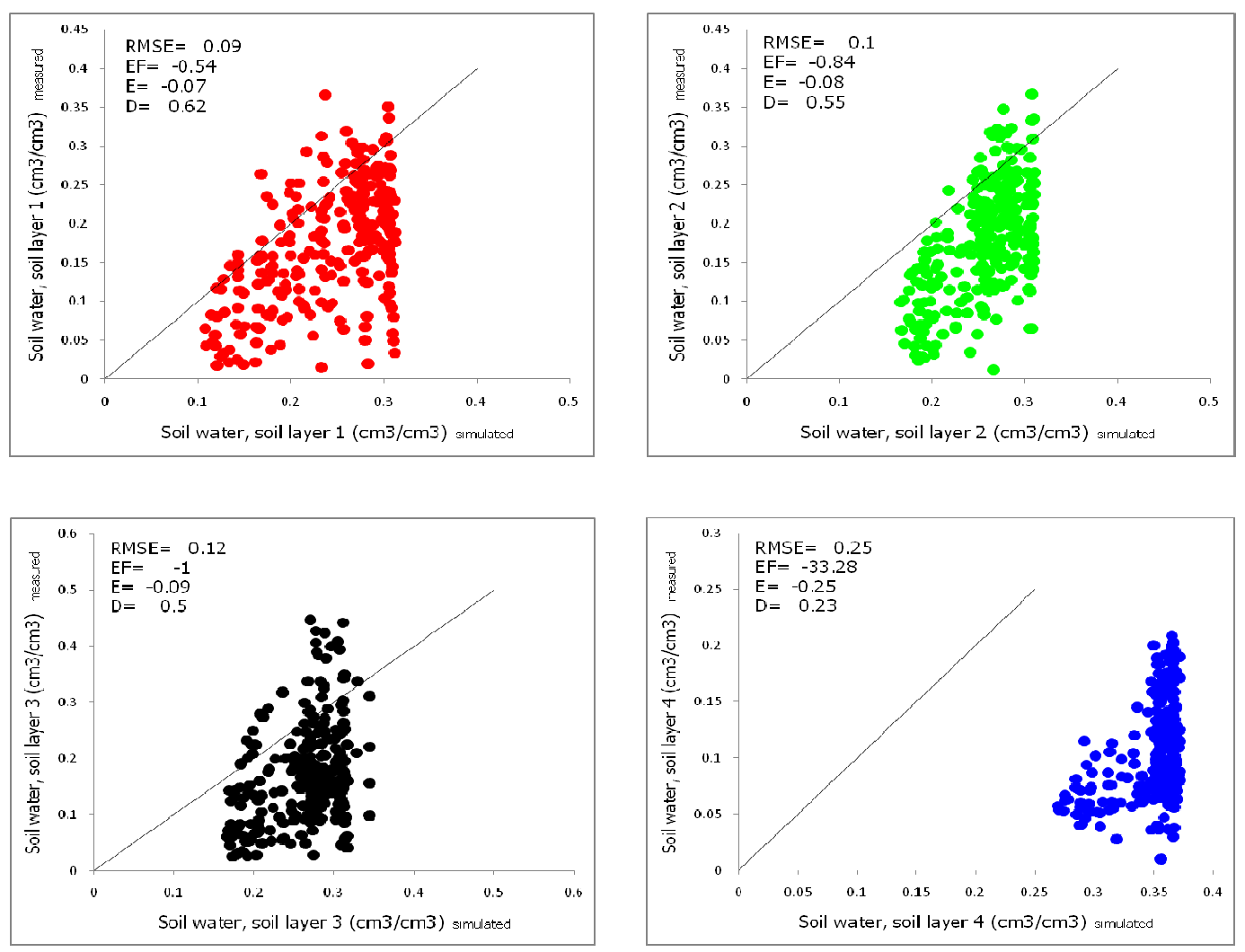

Figure 5. Evaluation statistics for soil water content (profile 1, 2, 3 and 4)

\subsection{Seasonal Analysis}

According to one seasonal analysis simulation, the box plot produced using CERES-maize model is presented in 
Figure 6. On application of $112 \mathrm{~kg} \mathrm{~N} /$ ha (PD2N1), the maximum average harvest maturity yield obtainable was $7265.0 \mathrm{~kg} / \mathrm{ha}$. Similarly, $168 \mathrm{~kg} \mathrm{~N} / \mathrm{ha}(\mathrm{PD} 1 \mathrm{~N} 2)$ gave a maximum average yield of $8311.0 \mathrm{~kg} / \mathrm{ha}$. However, the best treatment that guaranteed higher maximum grain yield was $168 \mathrm{~kg} \mathrm{~N} / \mathrm{ha}$ (PD1N2).

According to the seasonal analysis simulation for one season, Figure 6 shows result of cumulative probability of attaining harvest grain yield by specific treatment. For example at $100 \%$ cumulative probability, the maximum average maize grain yield was $8311.0 \mathrm{~kg} /$ ha for PD1N2. This implies that at $100 \%$ of the one seasonal simulation, no matter the management or agronomic practices that is employed, maize grain yield cannot exceed 8311.0 $\mathrm{kg} / \mathrm{ha}$ on application of $168 \mathrm{~kg} \mathrm{~N} / \mathrm{ha}$.
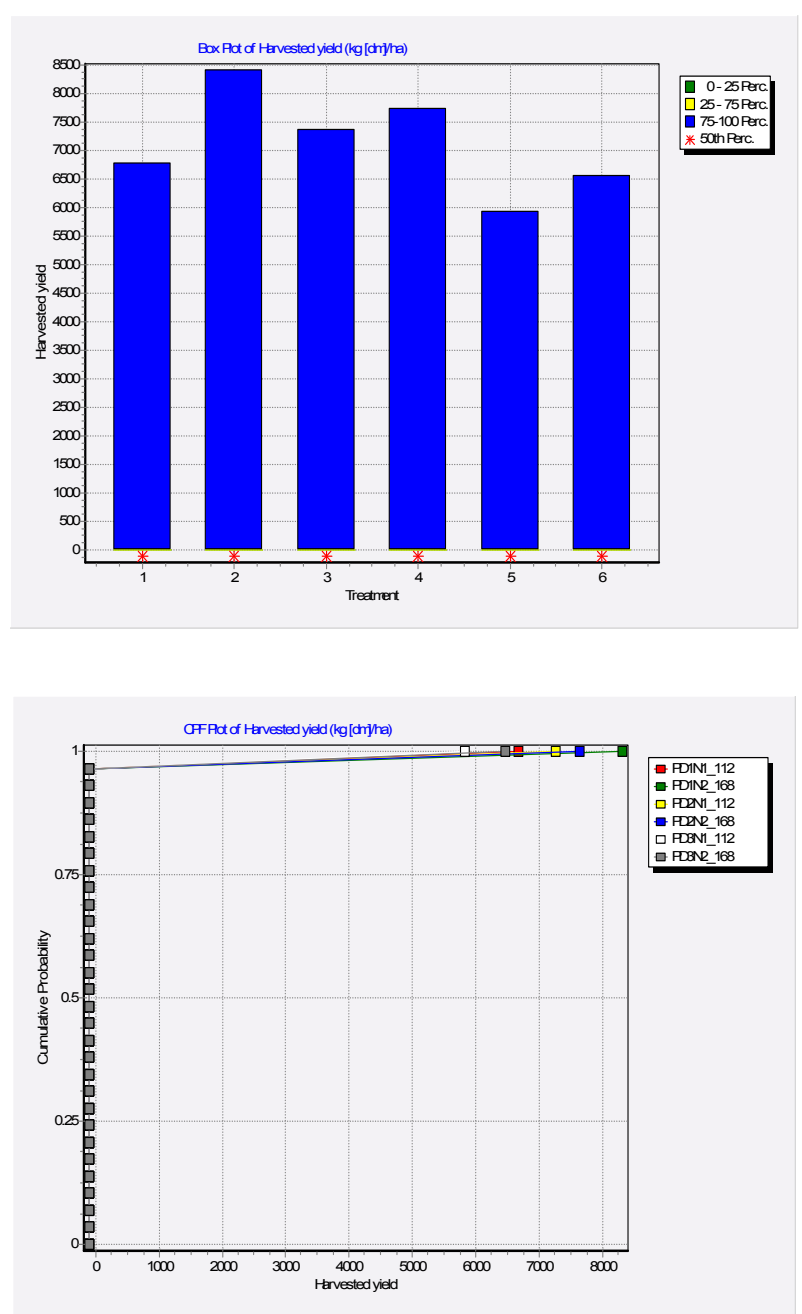

Figure 6. (i) Seasonal analysis of simulated average yield at harvest maturity (ii) Cumulative probability function plot of grain yield at maturity for one season

\section{Discussion}

Results ANOVA indicated that grain yield, aboveground biomass and stover were affected by the date of planting. Analysis of cumulative rainfall and mean minimum, and maximum air temperatures received during each period of maize growth reduced with delay in PD. This means that water and temperature being critical affected the rate of photosynthesis and dry matter accumulation (Reddy, 2006) from emergence to maturity (Streck, Lago, Gabriel, $\&$ Kaufmann, 2008). The coefficient of variation for grain yield and aboveground biomass were 9.0 and $8.2 \%$ respectively which was below $12 \%$ and considered efficient according to (K. Gomez \& A. Gomez, 1984). Poor amount of rainfall received during the third planting date may have had an effect of photosynthesis and accumulation of dry matter. Harvest index (HI) of grain and cobs $\left(\mathrm{g} \mathrm{m}^{-2}\right)$ were not significantly affected by nitrogen application rate at $\mathrm{P}<0.05$. The results of this study agree with (Muhammad et al., 2010) who also observed that $\mathrm{N}$ application rate did not affect $\mathrm{HI}$. 
The variation in planting date of maize determines the amount of solar radiation intercepted by the crop and thermal conditions during its growth. The amount of incident solar radiation and the proportion that is intercepted directly by the crop determines crop growth rate and its yield. Temperature is important and affects duration of crop growth and yield. Furthermore, the maximum time that the incident radiation can be intercepted is of particular importance in the length of the grain filling period since the dry matter accumulated in the grain in maize is largely from dry matter that accumulates after flowering. In environments of high light intensity and temperature, the higher water use efficiency (WUE) is due mainly to higher rates of photosynthesis by maize, which results in more dry matter (DM) accumulation (Abdrabbo et al., 2013). However, soil moisture deficit can occur quickly, especially during reproductive growth. Water loss in maize fields is primarily by surface evaporation from bare soil during early vegetative growth but shifts to evapotranspiration as the tassel begins to emerge and reproductive growth begins.

Emergence and anthesis day (dap) were accurately predicted by the CERES-maize model. Phenological development determination of the maize crop is generally influenced by the researcher experience and even a relatively small error in the stage description can greatly influence the overall statistical results. Soler et al. (2007) also reported close prediction of days to anthesis in maize by using CERES-maize model in different environments. The close agreement between the observed and simulated values for emergence and anthesis dates indicated that good phenological CSPs were assigned to ZMS606 cultivar used in this study. Robust crop simulation models such the CERES-maize model can play a role in evaluating the timing and amount of water application under limited water resources.

Grain production is usually more severely limited by reduced resources such as nitrogen application rates, water and air temperature (Raymond, 2007). Crop growth rate in pre-silking is important for allocation of assimilates to structural vegetative growth and maintenance respiration. Therefore, decrease in grain yield due to late planting would be associated with reducing rainfall, solar radiation and temperature.

Leaf area index (LAI) was simulated with less accuracy as indicated by the forecasting efficiency $(\mathrm{EF}=-0.63)$ and d-stat $(\mathrm{d}$-stat $=0.54)$. The results do not agree with (Jones \& Kiniry, 1986) evaluated the CERES-maize model using various data sets from different locations covering varying situations and it was observed that the simulated value of maximum LAI, aboveground biomass, grain number and grain yield were highly significantly correlated with measured values. The leaf area index had low coefficients of determination $\left(\mathrm{R}^{2}\right)$ due to poor performance of the model and the results of this study are supported by who reported that low coefficient of determination between predicted and observed values are due to poor performance by the model in representing crop yield responses to environmental factors.

Low nitrogen concentration in plants leaves is a factor that reduces the amount of radiation use efficiency (RUE) and biomass productivity. The accumulation of large amounts of nitrogen in the leave is essential for high biomass and grain yield and higher amounts of nitrogen are commonly associated with high harvest indices. Biomass production and nitrogen uptake by maize was studied by on fine sandy loam by applying $0,180,270 \mathrm{~kg}$ $\mathrm{N} \mathrm{ha}{ }^{-1}$. The results revealed that dry matter production and $\mathrm{N}$ uptake were much greater for treatment that received higher $\mathrm{N}$ application rates greater than zero. According to (Muhammad et al., 2010), various studies indicates that optimum fertilizer provide better crop yield and yield components. Researchers such as reported that increased yield components are due to application of high rate of $\mathrm{N}$ and the observed values in this study are supported by (El-Sheikh, 1998).

\section{Conclusion}

This manuscript evaluated the CERES-maize model in a split plot experiment including two factors of planting dates ( 3 levels) and nitrogen fertilizer application ( 2 levels). For each of the 6 combination of planting date and fertilizer treatment, the CERES-maize model was evaluated for crop growth and grain yield and soil water content. The CERES-maize model was calibrated, evaluated and it predicted phenology, biomass and grain yield under the two $\mathrm{N}$ application rates with reasonable accuracy. LAI, leaf weight and stem weight were simulated with less accuracy due to poor values of forecasting efficient and d-stat. Simulation of soil root water availability demonstrated that substantial potential yield may have been lost due to water stress under rain-fed conditions especially for the second and third date of planting. The results showed that the model can be used to accurately determine optimum planting date and nitrogen application rate under the local condition with reasonable accuracy.

\section{Acknowledgements}

This work was supported by the DSSAT team for the provision of the Decision Support System for Agrotechnology Transfer (DSSAT) software and licence. Financial support for this study is highly acknowledged 
with thanks from Alliance for a Green Revolution in Africa (AGRA), AGRA Coordinator and Southern African Science Service Centre for Climate Change and Adaptive Land Use (SASSCAL) Project 187/195.

\section{References}

Abdrabbo, M., Hashem, F., Elsayed, M., Abul-Soud, M., Farag, A., Hamada, M., \& Refaie, K. (2013). Evaluation of CSM-Ceres-Maize Model for Simulating Maize Production in Northern Delta of Egypt. Life Science Journal, 10(4), 3179-3192. Retrieved from http://www.lifesciencesite.com

Anothai, J., Soler, C., Green, A., Trout, T., \& Hoogenboom, G. (2013). Evaluation of two evapotranspiration approaches simulated with the CSM-CERES-Maize model under different irrigation strategies and the impact on maize growth, development and soil moisture content for semi-arid conditions. Agricultural and Forest Meteorology, 176, 64-76. http://dx.doi.org/10.1016/j.agrformet.2013.03.001

Black, C. (1965). Methods of Soil Analysis. Part 2. In C. Black (Ed.), American Society of Agronomy.

Bouyoucos, G. (1962). Hydrometer method improved for making particle size analysis of soils. Agron. J, 54, 464-465. http://dx.doi.org/10.2134/agronj1962.00021962005400050028x

Brockington, N. (1979). Computer Modeling in Agriculture. UK: Oxford University Press.

Bruce, W., Edmeades, G., \& Barke, T. (2002). Molecular and physiological approach to maize improvement for drought tolerance. Journal of Experimental Botany, 53, 13-25. http://dx.doi.org/10.1093/jexbot/53.366.13

CIAT. (2011). Integrate Soil Fertility Management Programme.

DeJong, K., Ascough, J., Andales, A., Hansen, N., Garcia, L., \& Arabi, M. (2012). Improving evapotranspiration simulations in the CERES-Maize model under limited irrigation. Agricultural Water Management, 115, 92-103. http://dx.doi.org/10.1016/j.agwat.2012.08.013

El-Sheikh, F. (1998). Effect of the application of nitrogen and folair application with manganese on grain yield and quality of maize (Zea mays L.). Proc. 8th Conf. Agron, 28-29 Nov. (pp. 182-189). Suez Canal Univ., Ismailia, Egypt.

Fageria, N., \& Baliger, V. (2005). Enhancing nitrogen use efficiency in crop plants. Advances in Agronomy, 88, 97-159. http://dx.doi.org/10.1016/S0065-2113(05)88004-6

Fairhurst, T. (2012). In T. Fairhurst (Ed.), Handbook for Integrated Soil Fertility Management. Nairobi: Africa Soil Health Consortium.

FARA. (2009). Patterns of Change in Maize Production in Africa: Implications for Maize Policy Development. Ministerial Policy Brief Series 3.

Gomez, K., \& Gomez, A. (1984). Statistical Procedures for Agriculture Research (2nd ed.). New York: John Wiley and Sons.

Hai-long, L., Jing-yi, Y., Ping, H., You-lu, J., Ji-yun, J., Drury, C., \& Hoogenboom, G. (2012). Optimizing Parameters of CSM-CERES-Maize Model to Improve Simulation Performance of Maize Growth and Nitrogen Uptake in Northeast China. Journal of Integrative Agriculture, 11, 1898-1913. http://dx.doi.org/10.1016/S2095-3119(12)60196-8

He, J., Porter, C., Wilkens, P., Marin, F., Hu, H., \& Jones, J. (2010). Guidelines for Installing and Running GLUE Program.

Hoogenboom, G., Jones, J. J., Porter, C., Wilkens, P., Boote, K., Hunt, L., \& Tsuji, G. (2010). Decision Support System for Agrotechnology Transfer Version 4.5. Volume 1: Overview (Vol. 1 Overview). University of Hawaii, Honolulu, HI.

Hoogenboom, G., Jones, J., Wilkens, P., Porter, C., Boote, K., Hunt, L., \& Koo, J. (2012). Decision Support System for Agrotechnology Transfer (DSSAT) Version DSSAT v4.5 [CD-ROM]. Honolulu, Hawaii: University of Hawaii.

Hoogenboom, G., Wilkens, P. W., \& Tsuji, G. Y. (1999). DSSAT v3, Volume 4. Honolulu, Hawaii: University of Hawaii.

Hsiao, T., Heng, L., Steduto, P., Rojas-Lara, B., Raes, D., \& Fereres, E. (2009). AquaCrop-The FAO crop model to simulate yield response to water: III. Parameterization and testing for maize. Agronomy Journal, 101(3), 448-459. http://dx.doi.org/10.2134/agronj2008.0218s 
IBSNAT. (1988). Experimental Design and Data Collection Procedures for IBSNAT. The minimum data set for systems analysis and crop simulation. IBSNAT Technical Report 1. Honolulu, HI: University of Hawaii.

Iglesias, A. (2006). Use of DSSAT models for climate change impact assessment: Calibration and validation of CERES-Wheat and CERES-Maize in Spain. Universidad Politecnica de Madrid.

Jeong, H., Jang, T., Seong, T., \& Park, S. (2014). Assessing Nitrogen fertilizer rates and splitapplications using the DSSAT model for rice irrigated with urban wastewater. Agric. Water Manage, 141, 1-9. http://dx.doi.org/10.1016/j.agwat.2014.04.009

Jones, C., \& Kiniry, J. (1986). CERES-Maize, A Simulation Model of Maize Growth and Development. College Station, TX: Texas A\&M University Press.

Jones, J. W., Hoogenboom, G., Porter, C. H., Boote, K. J., Batchelor, W. D., Hunt, L. A., ... Jones, J. (2003). DSSAT Cropping System Model. European Journal of Agronomy, 18, $235-265$. http://dx.doi.org/10.1016/S1161-0301(02)00107-7

Jones, J., He, J., Boote, K., Wilkens, P., Porter, C., \& Hu, Z. (2010b). In A. Ahuja \& L. Ma (Eds.), Estimating DSSAT Cropping System Cultivar-Specific Parameters Using Bayesian Techniques. Madison, WI: ASA, CSSA, and SSSA.

Jones, J., He, J., Boote, K., Wilkens, P., Porter, C., \& Hu, Z. (2011). Estimating DSSAT Cropping System Cultivar-Specific Parameters Using Bayesian Techniques. In L. Ahuja \& L. Ma (Eds.), Methods of Introducing System Models into Agricultural Research. Advances in Agricultural Systems Modeling 2. American Society of Agronomy. Madison, WI USA. http://dx.doi.org/10.2134/advagricsystmodel2.c13

Jones, J., Hoogenboom, G., Porter, C., Boote, K., Batchelor, W., Hunt, L., \& Ritchie, J. (2003). DSSAT Cropping System Model. European Journal of Agronomy, 18, 235-265. http://dx.doi.org/10.1016/S1161-0301(02)00107-7

Jones, J., Hoogenboom, G., Wilkens, P., Porter, C., \& Tsuji, G. (2010a). Decision Support System for Agrotechnology Transfer Version 4.5. Volume 3. DSSAT v4.5: ICASA Tools. Honolulu, HI: University of Hawaii.

Jones, M., \& Singles, A. (2008). DSSAT v4.5 - Canegro Sugarcane Plant Module. User Documentation. International Consortium for Sugarcane Modeling (ICSM). Retrieved from http://sasri.sasa.org.za/misc/icsm.html

Kihara, J., Fatondji, D., Jones, J., Hoogenboom, G., Tabo, R., \& Bationo, A. (2012). Improving Soil Fertility Recommendations in Africa using the Decision Support System for Agrotechnology Transfer (DSSAT). New York: Springer Dordrecht Heidelberg. http://dx.doi.org/10.1007/978-94-007-2960-5

Kiniry, J., Williams, R., Vanderlip, J., Atwood, D., Muuliken, W., Cox, H., ... Weibold, W. (1997). Evaluation of two maize models for nine U.S. locations. Agron. J., 89, 421-426. http://dx.doi.org/10.2134/agronj1997.00021962008900030009x

Kottek, J., Grieser, B., Rudolf, B., \& Rubel, F. (2006). World Map of the Köppen-Geiger climate classification updated. Meteorol. Z., 15, 259-263. http://dx.doi.org/10.1127/0941-2948/2006/0130

Lizaso, J., Boote, K., Jones, J., Porter, C., Echarte, L., Westgate, M., \& Sonohat, G. (2011). CSM-IXIM: A New Maize Simulation Model for DSSAT Version 4.5. Biometry, Modeling and Statistics. Agron. J., 103, 766-779. http://dx.doi.org/10.2134/agronj2010.0423

Lobell, D., \& Burke, M. (2010). On the use of statistical models to predict crop yield responses to climate change. Agric. Forest Meteorol. http://dx.doi.org/10.1016/j.agrformet.2010.07.008

Mohanty, M., Lenka, S., Chaudhary, R. S., \& Sinha, N. K. (2012). Training Manual Short Course on Use of Simulation Modeling in Climate Change Research: Special Reference to Natural Resource Management. Technical Report No.: IISS/SPD/2012. 3-12 October, 2012. Division of Soil Physics Indian Institute of Soil Science Nabibagh, Berasia Road, Bhopal-38 (MP).

Mubeen, M., Ahma, A., Aftab, W., Khaliq, T., \& Bakhsh, A. (2013). Evaluating CSM-CERES-Maize Model for Irrigation Scheduling inSemi-arid Conditions of Punjab, Pakistan. International Journal of Agriculture and Biology. Retrieved from http://www.fspublishers.org

Muchow, R., Sinclair, T., \& Bannett, J. (1990). Temperature and solar radiation effects on potential maize yield $\begin{array}{lllll}\text { across } & \text { locations. } & \text { Jgronomy }\end{array}$ http://dx.doi.org/10.2134/agronj1990.00021962008200020033x 
Muhammad, A., Amin, I., Jan, M., Munir, I., Nawab, K., Kkhan, N., \& Marwat, K. (2010). Effect of plant population and nitrogen levels and methods of application on ear characters and yield on maize. Pak. J. Bot, 42(3), 1959-1967.

Nagaraju. (2006). Studies on optimization of Agro-techniques to maximize productivity of winter maize (Zea mays L.) and evaluation of DSSAT v 3.5 CERES maize model (MSc Thesis). Dharwad University of Agricultural Sciences, Dharwad.

Ngwira, A., Aune, J., \& Thierfelde, C. (2014). DSSAT modelling of conservation agri-culture maize response to climate change in Malawi. Soil Tillage Res, 85-94. http://dx.doi.org/10.1016/j.still.2014.05.003

NSW DPI. (2009). Maize Growth and Development. State of New South Wales. NSW Department of Primary Industries.

Nurudeen, A. (2011). Decision Support System for Agrotechnology Transfer (DSSAT) model simulation of maize growth and yield response to NPK fertilizer application on a benchmark soil of Sudan Savanna Agro-ecological Zone of Ghana (MSc Thesis). Kwame Nkrumah Univ. of Sci. and Technology Kumasi.

Ollenburger, M. (2012). Modeling integrated soil fertility management options in Malawi under variable soil and climate conditions (MSc thesis). Michigan State University.

Page, A., Miller, R., \& Keeney, D. (1982). Methods of Soil Analysis, Part 2: Chemical and Microbiological Properties (2nd ed.). Madison, Wisconsin: American Society of Agronomy, Inc., and Soil Science Society of America.

Panda, R., \& Halder, D. (2010). Effect of Climate Change on Agro-environment and Coping Strategies under Eastern-Indian Conditions. Proc. of National Symposium on Climate Change and Rainfed Agriculture, Central Research Institute for Dryland Agriculture, Lead Paper, February 18-20 (pp. 97-105).

Pang, X., Letey, J., \& Wu, L. (1997). Yield and nitrogen uptake prediction by CERES-maize model under semiarid conditions. Soil Science Society of America Journal, 61, 254-256. http://dx.doi.org/10.2136/sssaj1997.03615995006100010035x

Ransom, J. (2013). Corn Growth and Management Quick Guide A1173. Fargo, North Dakota: North Dakota State University.

Raymond, F. (2007). Reducing Corn Yield Variability and Enhancing Yield Increases Through the Use of Corn-Specific Growth Models (MSc thesis). Blacksburg, Virginia.

Reddy, S. (2006). Agronomy of field crops (2nd ed.). New Delhi India: Kalyani Publishers.

Ritchie, J., Gerakis, A., \& Suleiman, A. (1999). Simple model to estimate field-measured soil water limits. Transactions of ASABE.

Ritchie, J., Godwin, D., \& Singh, U. (1989). The CERES models of crop growth and yield. Agron. Abs, 21.

Sentek. (2009). Diviner 2000 User Guide Version 1.5. Sentek Pty Ltd.

Soler, C., Sentelhas, P., \& Hoogenboom, G. (2005). Thermal time for phenological development of four maize hybrids grown off-season in a subtropical environment. J. Agric. Science, 143, 169-182. http://dx.doi.org/10.1017/S0021859605005198

Soler, C., Sentelhas, P., \& Hoogenboom, G. (2007). Application of the CSM-CERES-Maize model for planting date evaluation and yield forecasting for maize grown off-season in a subtropical environment. European Journal of Agronomy, 27(Issues 2-4), 165-177. http://dx.doi.org/10.1016/j.eja.2007.03.002

Streck, N., Lago, I., Gabriel, L., \& Kaufmann, S. (2008). Simulating maize phenology as a function of air temperature with a linear and a nonlinear model. Pesq. agropec. bras., Brasília, 43(4), 449-455.

Struif Bontkes, T., Singh, U., \& Chude, V. (2001). Problems and Opportunities in Adopting System Tools for Decision-Making Related to Soil Fertility Improvement in Africa. Integrated Natural Resource Management (INRM) Workshop. Cali, Colombia.

Thorp, K., Batchelor, W., Paz, J., Kaleita, A., \& DeJonge, K. (2007). Using Cross-Validation to Evaluate CERES-Maize Yield Simulations within a Decision Support System for Precision Agriculture. Transactions of the ASABE, 50(4), 1467-1479. http://dx.doi.org/10.13031/2013.23605

Timsina, J., \& Hunphreys, E. (2003). Performance and application of CERES and SWAGMAN Destiny models for rice-wheat cropping systems in Asia and Australia: a review. Technical Report 16/03. 
Tsimba, R. (2011). Development of a decision support system to determine the best maize (Zea mays L.) hybrid planting data option under typical New Zealand management system (PhD Thesis). Massey University, Palmerston North, New Zealand.

Uryasev, O., Gijsman, A., Jones, J., \& Hoogenboom, G. (2003). SBUILD createledit soil input files for evaluation and application on crop simulation models for DSSAT v4. Agricultural and Biological Engineering Department. Gainesville, FL: University of Florida.

USDA. (1984). Soil survey laboratory methods and procedures for collecting soil samples. Soil Survey Investigation Report No. 1. Washington, DC: U.S. Gov. Print Office.

Vučetić, V. (2006). Modeling of maize production and the impact of climate change on maize yield in Croatia. Meteorological and Hydrological Service.

Warrington, I., \& Kanemasu, E. (1983). Corn growth response to temperature and photoperiod: II. Leaf initiation and leaf appearance rates. Agronomy Journal, $755-761$. http://dx.doi.org/10.2134/agronj1983.00021962007500050008x

Willmott, C. (1982). Some comments on the evaluation of model performance. Bull. Am. Meteorol. Soc., 63, 1309-1313. http://dx.doi.org/10.1175/1520-0477(1982)063\%3C1309:SCOTEO\%3E2.0.CO;2

Yang, Z., Wilkerson, G., Buol, G., Bowman, D., \& Heiniger, R. (2009). Estimating Genetic Coefficients for the CSM-CERES-Maize Model in North Carolina Environments. Agron. J., 101, 1276-1285. http://dx.doi.org/10.2134/agronj2008.0234x

ZDA. (2011). Agriculture, Livestock and Fisheries Sector Profile. Zambia Agriculture Sector Profile, Lusaka, Zambia. Lusaka. Retrieved from http://www.zda.org.zm/sites/default/files/Sector\%20Profile\%20-\%20Agriculture.pdf

Zhou, X., Madramootoo, C., Machenzie, A., \& Smith, D. (1997). Biomass production and nitrogen uptake in $\begin{array}{lllll}\text { corn-ryegrass } & \text { systems. } & \text { Agronomy } & \text { Journal, } & \text { 89, }\end{array}$ http://dx.doi.org/10.2134/agronj1997.00021962008900050007x

\section{Notes}

Note1. R Core Team, 2009. Retrieved from http://www.R-project.org

\section{Copyrights}

Copyright for this article is retained by the author(s), with first publication rights granted to the journal.

This is an open-access article distributed under the terms and conditions of the Creative Commons Attribution license (http://creativecommons.org/licenses/by/3.0/). 